\title{
Assessment of Nutrient Deficiencies Based on Response of Rice (Oryza sativa L.) to Nutrient Omission in Inceptisols of Kondagaon District of Chhattisgarh in India
}

\author{
Balwant Kumar ${ }^{1}$, G.K. Sharma ${ }^{1 *}$, V.N. Mishra ${ }^{2}$, A. Pradhan ${ }^{1}$ and T. Chandrakar ${ }^{1}$ \\ ${ }^{1}$ Shaheed Gundadhur College of Agriculture and Research Station, Jagdalpur - 494005 \\ (Chhattisgarh), India \\ ${ }^{2}$ Department of Soil Science and Agricultural Chemistry, College of Agriculture, \\ Raipur - 492012 (Chhattisgarh), India \\ *Corresponding author
}

\section{A B S T R A C T}

The investigation was carried out at Shaheed Gundadhur College of Agriculture and Research Station, Jagdalpur with the objectives to identify the specific yield limiting nutrients through response of rice to nutrient omission in pot culture during kharif season, 2017 and to demonstrate the optimum use of identified limiting nutrients at field level in

\section{Keywords}

Yield limiting nutrients, Site specific nutrient management, Nutrient omission technique, Optimum nutrient doses

\section{Article Info}

Accepted:

04 August 2018

Available Online:

10 September 2018 wheat crop during rabi season 2017-18. The soil was a sandy clay loam, had a slightly acidic soil reaction ( $\mathrm{pH}$ 6.2), normal electrical conductivity, medium organic $\mathrm{C}$ and available $\mathrm{K}$, low available $\mathrm{N}, \mathrm{P}$, and $\mathrm{S}$, high available $\mathrm{Ca}, \mathrm{Mg}, \mathrm{Fe}, \mathrm{Mn}$ and $\mathrm{Cu}$ and marginal available $\mathrm{Zn}$ and $\mathrm{B}$. The experiment was laid out under completely randomized design with 3 replications and 11 treatments, formulated by keeping one treatment with application of all nutrients in optimum level and others by sequentially omitting each nutrient. Omission of $\mathrm{N}$ and $\mathrm{P}$ nutrients significantly reduced the different growth, yield and nutrients uptake parameters of rice in comparison to all nutrients. The maximum grain yield of $67.1 \mathrm{~g} \mathrm{pot}^{-1}$ was recorded, in all nutrients pot and $40.8 \%$ reduction in grain yield of rice, from the maximum yield, was recorded in $\mathrm{N}$ omitted pots, followed by $23.7 \%$ reduction in $\mathrm{P}$ omitted pots and omission of other nutrients didn't reduce the grain yield significantly indicating that only $\mathrm{N}$ and $\mathrm{P}$ were yield limiting nutrients. In field verification during rabi season, $17.8 \%$ increase in wheat grain yield and $20.9 \%$ increase in net return was recorded, due to optimum dose of identified yield limiting nutrients over farmer's practice dose.

\section{Introduction}

Adequate supply of plant nutrients decides optimum productivity of any cropping system. Even if, all other factors of crop production are in the optimum, the fertility of a soil largely determines the ultimate yield (Sekhon and Velayutham, 2002). When the soil does not supply sufficient nutrients for normal plant development and optimum productivity, application of supplemental nutrients is required. Fertilizer is one of the most important sources to meet this requirement. Indiscriminate use of fertilizers, however, may 
cause adverse effect on soils and crops both regarding nutrient toxicity and deficiency either by over use or inadequate use (Ray et al., 2000). Soil fertility evaluation, thus, is the key factor for adequate and balanced fertilization of crops in high crop production systems. Soil and plant analyses are commonly performed to assess the fertility status of a soil with other diagnostic techniques including identification of deficiency symptoms and biological tests which are helpful in determining specific nutrient stresses and quantity of nutrients needed to optimize the yield (Havlin et al., 2007). However, the analytical results do not indicate the most limiting nutrient according to Liebig's law of the minimum "the minimum nutrient is the factor that governs and controls growth and potential yield of crop".

A nutrients omission trial aims to find out the most limiting nutrients to the growth of a crop plant. If any element is omitted while other elements are applied at suitable rates and plants grow weakly, then the tested element is a limiting factor for crop growth. Conversely, if any element is omitted but plants are healthy, then that element is not a limiting factor for crop production. Conducting fertilizer field trials is an expensive task and time consuming process. This information can be generated through pot culture trial in controlled conditions through laboratory and greenhouses studies. This situation calls to identify the yield limiting nutrients for correcting the deficiencies and boosting the crop yield.

Rice (Oryza sativa), is an important staple food of India and continues to play a vital role in the national food and livelihood security system. India is having largest area under rice crop. However, productivity is lower than world's average productivity. The reason for low productivity is that rice is being grown in the country under various agro-ecologies in both irrigated and rainfed systems. States like Uttar Pradesh, Bihar, West Bengal, Orissa, Jharkhand, Chhattisgarh and Assam are having huge potential for rice cultivation and there is scope to increase productivity in this region.

The deficiency of some micro and secondary nutrients is one of the major causes for stagnation in crop productivity. Exploitive nature of modern agriculture involving use of high analysis NPK fertilizers, free from micronutrients as impurities, limited use of organic manures and restricted recycling of crop residues are some important factors having contributed towards accelerated exhaustion of secondary and micronutrients from soil. At several places, normal yield of crops could not be achieved despite balanced use of NPK due to micronutrient deficiency in soils (Sakal, 2001).

Chhattisgarh State has four major soils type i.e. Entisols, Inceptisols, Alfisols and Vertisols. Almost all soils are deficient in nitrogen and phosphorus and medium to high in potassium. Zinc deficiency is also reported in some patches of Alfisols and Vertisols of this region. In view of continuous use of sulfur free complex fertilizers, chances of increase in $S$ deficiency are likely. In addition to this limitation, low fertilizer efficiency, inadequacy of current fertilizer recommendations and the ignorance of nutrients other than $\mathrm{N}, \mathrm{P}$, and $\mathrm{K}$ may limit crop production. In view of continuous use of high analysis fertilizer, multiple nutrient deficiencies are likely. High crop yields can only be achieved by correcting such deficiencies. Site specific nutrient management is of utmost importance for obtaining high yields on sustainable basis (Sahu et al., 2017). However, little is known about the sustainability of the current production systems, particularly systems with multiple cropping under minimum practice. 
Looking to very limited information on the proper and site specific nutrient doses to maximize yield of rice, present investigation was undertaken with the objective to assess the yield limiting nutrients based on rice response to nutrient omission and to demonstrate the optimum use of identified limiting nutrients and its comparison with farmer's fertilizer practice.

\section{Materials and Methods}

\section{Location of the study}

Apot culture investigation was undertaken with the objectives to identify the specific yield limiting nutrients through response of rice (MTU-1001) to nutrient omission in Inceptisols of Kondagaon district, during the kharif season 2017 at the green house of Section of Soil Science and Agricultural Chemistry,Shaheed Gundadhoor College of Agriculture and Research Station, Jagdalpur, Bastar (Chhattisgarh) and subsequently a demonstration at farmers field at village Badebendri, block and district - Kondagaon to demonstrate the optimum use of identified limiting nutrients in wheat (GW-273) during rabi season 2017-18. The study site lies at $19^{0} 10^{\prime} \mathrm{N}$ latitude and $81^{\circ} 95 \mathrm{E}$ longitude with an altitude of 550-760 meter above the mean sea level.

\section{Initial characteristics of the experimental soils}

The Inceptisols, locally called Matasi, are immature soil with poor soil profile features having lighter texture and shallow to moderate depth. Soils are being used exclusive for growing early rice after bunding, puddling and leveling and for pulses and maize without bunding. They are soft and non-sticky when wet, easily workable under wet cultivation for puddling and biasi operation and therefore, can easily be managed to improve surface water retention for rice cultivation. Under this order the dominating sub-group is typic haplustept and Vertic haplustept. Vertic haplustept have clayey texture with clay content varying from 48.0 to $55.0 \%$. Typic haplustept is sandy clay loam to clay loam in texture with clay content raining from to 33.2 to $50.4 \%$. The initial physicochemical characteristics of the experimental soil (Inceptisol) were determined (Table 1) using common field and laboratory procedures. The experimental soil was a sandy clay loam, had a slightly acidic soil reaction ( $\mathrm{pH}$ 6.2), normal electrical conductivity, medium organic $\mathrm{C}$ and available $\mathrm{K}$, low available $\mathrm{N}, \mathrm{P}$, and $\mathrm{S}$, high available $\mathrm{Ca}, \mathrm{Mg}, \mathrm{Fe}, \mathrm{Mn}$ and $\mathrm{Cu}$ and marginal available $\mathrm{Zn}$ and $\mathrm{B}$ (Table 1).

\section{Experimental plan}

The experiment was laid out under completely randomized design with 3 replications and 11 treatments, formulated by keeping one treatment with application of all nutrients in optimum level and others by sequentially omitting each nutrient. Bulk soil samples representative of Inceptisols of the district was collected from the farmer's fields for pot culture experiment. The processed and uniformed soil samples were filled in plastic pots@20 kg and nutrients as specified above were applied through different sources taking care to avoid any precipitation during solution mixing and application. The optimum doses of nutrients were fixed in $\mathrm{kg} \mathrm{ha}^{-1}$ as $\mathrm{N}-150, \mathrm{P}_{2} \mathrm{O}_{5}$ - $100, \mathrm{~K}_{2} \mathrm{O}-100, \mathrm{~S}-45, \mathrm{Ca}-110, \mathrm{Mg}-50, \mathrm{Fe}$ - 20, $\mathrm{Mn}-7.5, \mathrm{Cu}-7.5, \mathrm{Zn}-7.5, \mathrm{~B}-3$ and $\mathrm{Mo}$ - 0.75 for SSNM dose. Rice (MTU-1001) was taken as test crop. The pots were maintained saturation with standing water and twenty five days old seedlings of rice (MTU-1001) were transplanted on $22^{\text {th }}$ July 2017. Three seedlings of MTU-1001 variety of rice were planted in three hills in each pot and water level was maintained at $3 \mathrm{~cm}$ throughout the crop season. Thereafter, full dose of all the 
nutrients except nitrogen was added to the soil in solution form. Nitrogen as urea was applied in three splits at transplanting, tillering and panicle initiation stage. Crop was grown till maturity and harvested on 17 th November, 2017. The effects of treatments were recorded in terms of yield, different yield attributing parameters and nutrient uptake by rice crop. Based on these results, $\mathrm{N}$ and $\mathrm{P}$ nutrients were identified as yield limiting nutrients. The optimum use of limiting nutrients was demonstrated at farmer's field, from where the bulk soil was collected, with wheat variety GW-273 as a test crop during rabi season 2017-18. The wheat crop was sown on $14^{\text {th }}$ Dec 2017 and harvested on 14th April 2018. The farmer's used fertilizer dose at the rate of $80 \mathrm{kgN}: 50 \mathrm{kgP}_{2} \mathrm{O}_{5}: 30 \mathrm{~kg} \mathrm{~K}_{2} \mathrm{O} \mathrm{ha}^{-1}$. The effects of optimum/SSNM dose was compared with farmer's fertilizer practice.

\section{Results and Discussion}

\section{Growth and yield attributes of rice}

\section{Plant height}

Omission of nutrients had a significant effect on plant height of rice crop (Table 2). Plant height is one of the most important characteristics which indicate nutrients absorption capacity as well as health of the soil and plant. The highest plant height of rice was recorded under treatment where all the nutrients were supplied, whereas significantly lower plant height was recorded under the treatments missing $\mathrm{N}$, and $\mathrm{P}$ nutrients.

\section{Number of tillers pot ${ }^{-1}$}

Significantly higher number of tillers pot $^{-1}$, recorded at 60 days after transplanting of rice, was observed in treatment that received all nutrients and on the other hand, omission of $\mathrm{N}$ and $\mathrm{P}$ nutrients significantly reduced the number of tillers $\operatorname{pot}^{-1}$ in comparison to all nutrients (Table 2). Omission of other nutrients didn't reduce the number of tillers pot $^{-1}$ significantly. $\mathrm{N}$ plays a key role in tillers bearing of rice followed by $\mathrm{P}$. On an average, 21.3 tillers pot $^{-1}$ was observed, at 60 DAT, with treatment that received all nutrients and various nutrients omission treatments had reduced number of tillers. Omission of $\mathrm{N}$ and $P$ reduced the number of tillers significantly as these two nutrients have major role in tillers bearing of the crop. Many researchers have also concluded the importance of $\mathrm{N}$ and $\mathrm{P}$ in tillering of rice (Singh, 2008, Sahu et al., 2017).

\section{Number of effective tillers pot $^{-1}$}

Omission of $\mathrm{N}$ and $\mathrm{P}$ nutrients significantly reduced the effective tillerspot $^{-1}$ of rice as compared to treatment that received all nutrients. Other nutrients omission didn't reduce the effective tillers pot $^{-1}$ of rice.

\section{Number of filled grains panicle ${ }^{-1}$}

Similar trend was also observed for number of filled grains per panicle of rice which varied from 112.3 to 142.0 . The treatments missing $\mathrm{N}$ and $\mathrm{P}$ nutrients recorded significantly reduced number of filled grains per panicle as compared to treatment which received all nutrients (Table 2).

\section{Test weight}

A close examination of the data pertaining to test weight (1000 grain weight) presented in Table 2 showed that the test weight of rice grain didn't varied significantly with different treatments. In general, the test weight of rice grain varied from 25.2 to $26.0 \mathrm{~g}$ per1000 grains. However, omission of $\mathrm{N}$ and $\mathrm{P}$ pots had reduced the test weight as compared to those of all other treatments. It is universally truth that $\mathrm{N}$ and $\mathrm{P}$ are the most important major nutrients require for tillering, root growth and 
general plant vigor that affect ultimately filled grains and test weight. The reduced effective tillers, number of filled grains per panicle and test weight were recorded in present study because of omission of $\mathrm{N}$ and $\mathrm{P}$ nutrients.

Since $\mathrm{N}$ is an important constituent of amino acids, proteins and protoplast, its application had a more pronounced effect on plant growth and development through better utilization of photo-synthates and more vegetative growth. These results are in conformity of the findings of Singh, (2008) and Sharma et al., (2000). P omission had also exhibited a significant effect on plant height. Optimum $\mathrm{P}$ availability is essential for normal growth and development and the utilization of other nutrients, particularly N. The significant crop response to $\mathrm{P}$ application was also reported by many workers (Ahmed et al., 2010 and Mc Beath et al., 2007).

\section{Yield of rice}

\section{Grain yield}

The maximum grain yield (67.1 $\left.\mathrm{g} \mathrm{pot}^{-1}\right)$ was recorded under the treatment receiving all the nutrients and that of the lowest grain yields (39.7 $\mathrm{g} \mathrm{pot}^{-1}$ ) was recorded under omission of $\mathrm{N}$ followed by omission of $\mathrm{P}\left(51.2 \mathrm{~g} \mathrm{pot}^{-1}\right)$ nutrients. Omission of $\mathrm{N}$ and $\mathrm{P}$ nutrients significantly reduced the grain yield of rice in comparison to the treatment that received all nutrients. In other treatments, grain yields were observed statistically at par in comparison to treatment where all the nutrients were supplied to rice crop (Table 2).

\section{Grain yield reduction}

The reduction of rice grain yield because of omission of different plant nutrients, from treatment that received all nutrients, wasalso worked out (Table 2). The yield limiting nutrients which reduced the yield by about
$10 \%$ from the maximum yield obtained by treatment receiving all nutrients, was critically observed. It was noticed that omission of $\mathrm{N}$ reduced the grain yield of rice by $40.8 \%$ and $\mathrm{P}$ omission caused a reduction of $23.7 \%$ in grain yield of rice. Large reductions in the grain yield of rice were observed with the omission of $\mathrm{N}$ and $\mathrm{P}$ as compared to the other nutrient omission treatments. The yield reductions were more pronounced with $\mathrm{N}$ omission. Result clearly indicates that $\mathrm{N}$ is the most critical nutrients that affect the grain yield considerably followed by P. Omission of all other nutrients did not indicate yield reduction.

\section{Straw yield}

It is evident from the data in Table 2 that the mean straw yields of rice were significantly affected with imposition of different nutrient omission treatments. Omission of $\mathrm{N}$ and $\mathrm{P}$ significantly reduced the straw yield as compared to treatment where all the nutrients were supplied. The highest straw yield $(83.0 \mathrm{~g}$ pot $^{-1}$ ) of rice was observed in treatment that omit $\mathrm{Ca}$ which was at par with treatment where all the nutrients were applied and lowest $\left(50.8\right.$ pot $\left.^{-1}\right)$ in treatment where $\mathrm{N}$ was omitted followed by $\mathrm{P}$ omission treatment.

\section{Primary nutrient uptake}

\section{N uptake}

The data in Table 3 indicated that the nitrogen uptake by rice was significantly affected with application of different missing nutrient treatments. Omission of $\mathrm{N}$ and $\mathrm{P}$ significantly reduced the $\mathrm{N}$ uptake by rice as compared to treatment where all the nutrients were supplied. The highest $\mathrm{N}$ uptake of $1.12 \mathrm{~g} \mathrm{pot}^{-1}$ was recorded in the treatment that received all the nutrients and that of the lowest $\mathrm{N}$ uptake of $0.65 \mathrm{~g} \mathrm{pot}^{-1}$ was recorded in the pots where $\mathrm{N}$ was omitted. Supply of all the nutrients 
including nitrogen in "All" treatment increased the grain and straw yields as well as the nitrogen concentrations causing more uptake of $\mathrm{N}$ (Syed et al., 2006). Minimum nitrogen uptake was observed with nitrogen omission because nitrogen was the most yield limiting nutrient which resulted in lower yields and lower nitrogen uptake. The similar findings were also reported by Mishra et al., (2007).

\section{Phosphorus uptake}

The highest total uptake of $\mathrm{P}$ by rice was recorded to the tune of $0.26 \mathrm{~g} \mathrm{pot}^{-1}$ under the treatment where all the nutrients were applied. Whereas the lowest total $\mathrm{P}$ uptake $(0.15 \mathrm{~g}$ pot $^{-1}$ ) was observed in the treatment that missed N. Reductions in $\mathrm{P}$ uptake with omission of $\mathrm{N}$ and $\mathrm{P}$ have also been reported by Mishra et al., (2007) for rice crop and similar reductions in $\mathrm{P}$ concentration with omission of $\mathrm{P}$ have also been reported by Din et al., (2001) for chickpea. Supply of P in "All" treatment increased the soil solution $\mathrm{P}$ causing higher absorption of $\mathrm{P}$ resulting in higher grain and straw yields as well more uptake of $\mathrm{P}$ because $\mathrm{P}$ was the next most yield limiting nutrient after $\mathrm{N}$, which resulted in lower yields and lower $\mathrm{P}$ concentrations.

\section{Potassium uptake}

The highest $\mathrm{K}$ uptake (1.37 $\mathrm{g}$ pot $\left.^{-1}\right)$ was observed in the treatment that received all the nutrients and $\mathrm{Ca}$ omitted pots and the lowest $\mathrm{K}$ uptake $\left(0.83 \mathrm{~g} \mathrm{pot}^{-1}\right)$ were registered in the $\mathrm{N}$ omission treatment followed by $\mathrm{P}$ omission treatment. Omission of $\mathrm{N}$ and $\mathrm{P}$ nutrients significantly reduced the $\mathrm{K}$ uptake by rice in comparison to treatment that received all nutrients.

Table.1 Initial physicochemical characteristics of experimental soils

\begin{tabular}{|c|c|c|c|}
\hline S. No. & Soil Characteristics & Value & Rating \\
\hline \multirow[t]{4}{*}{1.} & Mechanical Analysis & & \\
\hline & Sand $(\%)$ & 55 & \multirow{3}{*}{ Sandy clay loam } \\
\hline & Silt (\%) & 24 & \\
\hline & Clay $(\%)$ & 21 & \\
\hline 2. & pH (1:2.5 soil: water suspension) & 6.2 & Slightly acidic \\
\hline 3. & Electrical Conductivity $\left(\mathrm{dS} \mathrm{m}^{-1}\right)$ & 0.14 & Normal \\
\hline 4. & Organic C (\%) & 0.55 & Medium \\
\hline 5. & N Available $\left(\mathrm{kg} \mathrm{ha}^{-1}\right)$ & 247 & Low \\
\hline$\overline{6 .}$ & P Available $\left(\mathrm{kg} \mathrm{ha}^{-1}\right)$ & 10.0 & Low \\
\hline 7. & K Available $\left(\mathrm{kg} \mathrm{ha}^{-1}\right)$ & 158 & Medium \\
\hline 8. & S Available $\left(\mathrm{kg} \mathrm{ha}^{-1}\right)$ & 18.4 & Low \\
\hline 9. & Ca Available $\left(\mathrm{kg} \mathrm{ha}^{-1}\right)$ & 1040 & High \\
\hline 10. & Mg Available $\left(\mathrm{kg} \mathrm{ha}^{-1}\right)$ & 496 & High \\
\hline 11. & Fe Available $\left(\mathrm{mg} \mathrm{kg}^{-1}\right)$ & 60.36 & High \\
\hline 12. & Mn Available (mg kg $\left.{ }^{-1}\right)$ & 21.91 & High \\
\hline 13. & Zn Available (mg kg-1) & 0.97 & Marginal \\
\hline 14. & Cu Available (mg kg $\left.{ }^{-1}\right)$ & 1.14 & High \\
\hline 15. & B Available (mg kg $\left.{ }^{-1}\right)$ & 0.53 & Marginal \\
\hline
\end{tabular}


Table.2 Effect of nutrient omission on yield and yield attributes of rice (MTU-1001) in Inceptisol of Kondagaon district of Chhattisgarh

\begin{tabular}{|c|c|c|c|c|c|c|c|c|}
\hline Treatments & $\begin{array}{l}\text { Plant height } \\
\text { (cm) }\end{array}$ & $\begin{array}{l}\text { Tillers (No. pot } \\
\text { 1) }\end{array}$ & $\begin{array}{l}\text { Effective tillers } \\
\left(\text { No. pot }{ }^{-1}\right)\end{array}$ & $\begin{array}{l}\text { Filled grains } \\
\text { (No. panicle }^{-1} \text { ) }\end{array}$ & $\begin{array}{l}\text { Test weight (g } \\
1000 \text { grains }^{-1} \text { ) }\end{array}$ & $\begin{array}{c}\text { Grain yield ( } \mathrm{g} \\
\text { pot }^{-1} \text { ) }\end{array}$ & $\begin{array}{c}\text { Grain yield } \\
\text { reduction }(\%)\end{array}$ & $\begin{array}{c}\text { Straw yield (g } \\
\left.\text { pot }^{-1}\right)\end{array}$ \\
\hline All & 99.6 & 21.3 & 18.3 & 142.0 & 26.0 & 67.1 & - & 82.5 \\
\hline All-N & 85.4 & 16.7 & 13.7 & 112.3 & 25.2 & 39.7 & 40.8 & 50.8 \\
\hline All-P & 93.3 & 18.7 & 15.7 & 118.7 & 25.6 & 51.2 & 23.7 & 63.9 \\
\hline All-K & 99.0 & 20.7 & 17.7 & 140.0 & 26.0 & 64.0 & 4.6 & 80.8 \\
\hline All-S & 96.4 & 20.3 & 18.0 & 129.0 & 25.9 & 61.0 & 9.1 & 76.5 \\
\hline All-Ca & 99.5 & 21.0 & 18.0 & 137.0 & 25.9 & 65.0 & 3.1 & 83.0 \\
\hline All-Mg & 98.4 & 20.3 & 18.0 & 136.7 & 25.9 & 63.5 & 5.4 & 80.9 \\
\hline All-Cu & 99.4 & 20.7 & 18.3 & 138.0 & 25.9 & 65.4 & 2.5 & 81.0 \\
\hline All-Zn & 98.1 & 20.7 & 18.0 & 136.0 & 25.9 & 63.2 & 5.8 & 78.4 \\
\hline All-B & 97.6 & 20.7 & 17.3 & 138.3 & 25.9 & 62.8 & 6.4 & 77.5 \\
\hline All-Mo & 97.5 & 20.7 & 17.3 & 141.3 & 25.9 & 62.4 & 7.0 & 79.6 \\
\hline SEm $( \pm)$ & 1.02 & 0.65 & 0.80 & 5.77 & 0.24 & 2.40 & - & 3.02 \\
\hline CD at 5\% level & 3.03 & 1.94 & 2.39 & 17.13 & NS & 7.13 & - & 8.97 \\
\hline
\end{tabular}

Table.3 Effect of nutrient omission on total uptake of nutrients by rice (MTU-1001) in Inceptisol of Kondagaon district of Chhattisgarh

\begin{tabular}{|c|c|c|c|c|c|c|c|c|c|c|c|}
\hline \multirow[t]{2}{*}{ Treatments } & \multicolumn{3}{|c|}{ Primary Nutrients $\left(\mathrm{g}\right.$ pot $\left.^{-1}\right)$} & \multicolumn{3}{|c|}{ Secondary Nutrients $\left(\mathrm{g} \mathrm{pot}^{-1}\right)$} & \multicolumn{5}{|c|}{ Micronutrients(mg pot $\left.{ }^{-1}\right)$} \\
\hline & $\mathbf{N}$ & $\mathbf{P}$ & $\mathbf{K}$ & $\mathbf{C a}$ & Mg & $\mathbf{S}$ & $\mathbf{F e}$ & Mn & $\mathbf{Z n}$ & $\mathrm{Cu}$ & B \\
\hline All & 1.12 & 0.26 & 1.37 & 0.69 & 0.40 & 0.18 & 21.4 & 30.7 & 4.3 & 0.90 & 1.20 \\
\hline All - $\mathbf{N}$ & 0.65 & 0.15 & 0.83 & 0.41 & 0.23 & 0.10 & 12.6 & 17.8 & 2.6 & 0.53 & 0.73 \\
\hline All - $\mathbf{P}$ & 0.85 & 0.17 & 1.05 & 0.52 & 0.30 & 0.13 & 16.3 & 23.0 & 3.3 & 0.68 & 0.93 \\
\hline All - K & 1.07 & 0.24 & 1.27 & 0.66 & 0.37 & 0.17 & 20.5 & 29.0 & 4.0 & 0.86 & 1.17 \\
\hline All - S & 1.02 & 0.23 & 1.26 & 0.62 & 0.36 & 0.17 & 19.7 & 26.5 & 3.9 & 0.83 & 1.11 \\
\hline All - Ca & 1.09 & 0.25 & 1.37 & 0.63 & 0.38 & 0.18 & 21.1 & 29.5 & 4.1 & 0.87 & 1.18 \\
\hline All - Mg & 1.06 & 0.24 & 1.33 & 0.66 & 0.36 & 0.17 & 20.6 & 29.1 & 4.1 & 0.86 & 1.15 \\
\hline All - $\mathrm{Cu}$ & 1.08 & 0.24 & 1.35 & 0.66 & 0.37 & 0.17 & 20.8 & 29.6 & 4.1 & 0.87 & 1.18 \\
\hline All - Zn & 1.04 & 0.24 & 1.31 & 0.65 & 0.36 & 0.17 & 20.4 & 27.8 & 4.0 & 0.85 & 1.14 \\
\hline All - Bo & 1.04 & 0.23 & 1.28 & 0.63 & 0.36 & 0.17 & 20.7 & 27.4 & 3.8 & 0.84 & 1.13 \\
\hline All - Mo & 1.04 & 0.23 & 1.31 & 0.64 & 0.37 & 0.17 & 20.2 & 28.6 & 3.9 & 0.85 & 1.14 \\
\hline SEm \pm & 0.045 & 0.012 & 0.056 & 0.029 & 0.016 & 0.004 & 1.00 & 1.54 & 0.22 & 0.04 & 0.04 \\
\hline $\begin{array}{c}\text { CD at } 5 \% \\
\text { level }\end{array}$ & 21.4 & 30.7 & 4.3 & 0.90 & 1.20 & 21.4 & 2.95 & 4.53 & 0.64 & 0.11 & 0.13 \\
\hline
\end{tabular}


Table.4 Grain yield and economics of wheat in relation to SSNM and Farmer's fertilizer dose in Inceptisol of Kondagaon district

\begin{tabular}{|c|c|c|c|c|c|c|}
\hline S. No. & $\begin{array}{l}\text { Nutrient } \\
\text { Dose }\end{array}$ & $\begin{array}{l}\text { Yield (q } \\
\left.\text { ha }^{-1}\right)\end{array}$ & $\begin{array}{c}\text { Cost of cultivation } \\
\left(\text { Rs. ha } \mathbf{h a}^{-1}\right)\end{array}$ & $\begin{array}{l}\text { Gross return } \\
\left(\text { Rs. } \text { ha }^{-1}\right)\end{array}$ & $\begin{array}{l}\text { Net return (Rs. } \\
\left.\text { ha }^{-1}\right)\end{array}$ & $\begin{array}{c}\text { B:C ratio (Rs. } \\
\left.\operatorname{Re}^{-1}\right)\end{array}$ \\
\hline 1 & SSNM & 28.4 & 32214 & 56800 & 24586 & 1.76 \\
\hline 2 & FFD & 24.1 & 27869 & 48200 & 20331 & 1.73 \\
\hline \multicolumn{2}{|c|}{ Difference } & 4.3 & 4345 & 8600 & 4255 & 0.03 \\
\hline \multicolumn{2}{|c|}{$\%$ Change } & 17.8 & 15.6 & 17.8 & 20.9 & 1.9 \\
\hline
\end{tabular}

Secondary Nutrients uptake

\section{Calcium uptake}

The highest $\mathrm{Ca}$ uptake $\left(0.69 \mathrm{~g}^{-1}\right)$ by rice crop was observed in treatment that received all the nutrients. Omission of $\mathrm{N}$ and $\mathrm{P}$ nutrients significantly reduced the $\mathrm{Ca}$ uptake in comparison to the maximum, and the least uptake was observed in $\mathrm{N}$ omission $(0.41 \mathrm{~g}$ $\left.\operatorname{pot}^{-1}\right)$ followed by $\mathrm{P}$ omission $\left(0.52 \mathrm{~g} \mathrm{pot}^{-1}\right)$ pots. Omission of $\mathrm{N}$ and $\mathrm{P}$ reduced the uptakes more than that of omission of other nutrients indicating that these two nutrients were the most limiting nutrients. Lower $\mathrm{Ca}$ uptakes were observed with $\mathrm{N}$ and $\mathrm{P}$ omission obviously due to lower grain and straw yields and lower $\mathrm{Ca}$ concentrations. Uptakes of $\mathrm{Ca}$ in $\mathrm{N}$ and $\mathrm{P}$ omitted pots were in the order of $\mathrm{N}$ $<\mathrm{P}$ in accordance with the grain and straw yields and $\mathrm{Ca}$ concentrations in the respective pots.

\section{Magnesium uptake}

The highest total uptake of $\mathrm{Mg}$ was observed with the treatment receiving all the nutrients $\left(0.40 \mathrm{~g} \mathrm{pot}^{-1}\right)$ because supply of all the nutrients including $\mathrm{Mg}$ in All treatments increased the grain and straw yields as well as the $\mathrm{Mg}$ concentrations causing more uptakes of $\mathrm{Mg}$. Whereas, the least $\mathrm{Mg}$ uptakes $(0.23$ and $0.30 \mathrm{~g} \mathrm{pot}^{-1}$ ) was observed with $\mathrm{N}$ and $\mathrm{P}$ omission since these elements were the most yield limiting in the soil. $\mathrm{Mg}$ uptakes were found almost similar in all the other treatments in comparison to all nutrients which might be due to higher initial $\mathrm{Mg}$ content in soil. Uptakes of $\mathrm{Mg}$ in $\mathrm{N}$ and $\mathrm{P}$ omitted pots were in the order of $\mathrm{N}<\mathrm{P}$ in accordance with the grain and straw yields and $\mathrm{Mg}$ concentrations in the respective pots.

\section{Sulphur uptake}

The highest $\mathrm{S}$ uptake $\left(0.18 \mathrm{~g} \mathrm{pot}^{-1}\right)$ was recorded in treatment which received all nutrients and the least total uptake of $\mathrm{S}$ was observed in the treatment that omit $\mathrm{N}$ nutrient. Omission of $\mathrm{N}$ and $\mathrm{P}$ caused significantly reduced uptake of $\mathrm{S}$, in comparison to treatment that received all the nutrients.

\section{Micronutrients uptake by rice}

\section{Fe uptake}

The highest Fe uptake $\left(21.4 \mathrm{mg} \mathrm{pot}^{-1}\right)$ was associated with the treatment receiving all the nutrients, closely followed by omission of $\mathrm{Ca}$, $\mathrm{Cu}, \mathrm{B}, \mathrm{Mg}, \mathrm{K}, \mathrm{Zn}, \mathrm{Mo}$, and $\mathrm{S}$ respectively and were statistically at par with each other and significantly higher than $\mathrm{Fe}$ uptake in $\mathrm{N}$ and $\mathrm{P}$ omission treatments. The lowest $\mathrm{Fe}$ uptake (12.6 mg pot ${ }^{-1}$ ) was recorded in $\mathrm{N}$ omission treatment followed by $\mathrm{P}\left(16.3 \mathrm{mg} \operatorname{pot}^{-1}\right)$ omission treatment.

\section{Mn uptake}

The significant reduction in uptake of Mn was observed in $\mathrm{N}$ and $\mathrm{P}$ omission treatments than 
the uptake observed with treatment receiving all nutrients. The total uptake of $\mathrm{Mn}$ was found maximum $\left(30.7 \mathrm{mg} \operatorname{pot}^{-1}\right)$ in the treatment where all the nutrients was applied which was statistically at par with other treatments except $\mathrm{N}$ and $\mathrm{P}$. The least $\mathrm{Mn}$ uptake $\left(17.8 \mathrm{mg} \mathrm{pot}^{-1}\right)$ was recorded in the treatment where $\mathrm{N}$ was omitted followed by $\mathrm{P}$ (13.0 mg pot ${ }^{-1}$ ) omission treatment.

\section{Zinc uptake}

Total uptake of $\mathrm{Zn}\left(4.3 \mathrm{mg}\right.$ pot $\left.^{-1}\right)$ by rice was found maximum in the treatment receiving all the nutrients and minimum $\left(2.6 \mathrm{mg} \mathrm{pot}^{-1}\right)$ in the treatment where $\mathrm{N}$ was omitted. Significantly reduced $\mathrm{Zn}$ uptake was observed with omission of $\mathrm{N}$ and $\mathrm{P}$ as compared to treatment receiving all the nutrients and uptake in other treatments was found at par with it.

\section{Cu uptake}

The significant reduction in uptake of $\mathrm{Cu}$ $\left(0.53 \mathrm{mg} \mathrm{pot}^{-1}\right)$ was found in $\mathrm{N}$ omission pot followed by $\mathrm{P}\left(0.68 \mathrm{mg}^{-1}\right)$ omission and both were significantly lower than the $\mathrm{Cu}$ uptake $\left(0.90 \mathrm{mg} \mathrm{pot}^{-1}\right)$ observed with the treatment receiving all the nutrients which recorded maximum uptake and statistically at par with $\mathrm{Cu}$ uptake in $\mathrm{K}, \mathrm{S}, \mathrm{Ca}, \mathrm{Mg}, \mathrm{Cu}, \mathrm{Zn}$, $\mathrm{B}$ and Mo omitted pots.

\section{B uptake}

Omission of $\mathrm{N}$ and $\mathrm{P}$ nutrients caused significant reduction in the total $\mathrm{B}$ uptake by rice over treatment receiving all nutrients (Table 3). It was found maximum $(1.20 \mathrm{mg}$ $\left.\operatorname{pot}^{-1}\right)$ in the treatment where all the nutrients were applied and minimum $\left(0.73 \mathrm{mg} \mathrm{pot}^{-1}\right)$ in the where $\mathrm{N}$ was omitted followed by uptake of $\mathrm{B}$ in $\mathrm{P}\left(0.93 \mathrm{mg} \mathrm{pot}^{-1}\right)$ omission treatment. $\mathrm{Mo}, \mathrm{Cu}, \mathrm{K}, \mathrm{S}, \mathrm{Mg}$, $\mathrm{Ca}$ and $\mathrm{Zn}$ omitted pots were statistically at par with each other and that with the treatment receiving all the nutrients.

\section{Field verification of identified yield limiting} nutrients

Based on the response of rice crop to nutrients omission, the yield limiting nutrients identified was $\mathrm{N}$ and $\mathrm{P}$. They were verified in a verification trial at farmers field, from where the bulk soil was collected for pot experiment, through applying optimum/SSNM dose of these nutrients in wheat during rabi season 2017-18. The final grain yields of wheat at farmer's fields under both the doses were recorded and the comparison is presented in Table 4. The wheat grain yields at farmer's fields was higher in SSNM dose applied, based on yield limiting nutrients, as compared to that of farmer's practice dose. The economic analysis of both the fertilizer doses revealed that the SSNM dose had higher gross return, net return and $\mathrm{B}$ : $\mathrm{C}$ ratio as compared to farmers practice dose, thus, it confirmed that $\mathrm{N}$ and $\mathrm{P}$ was the yield limiting nutrients and the SSNM dose was economically profitable to the farmers.

\section{References}

Ahmed, S., Elahi, N., Khan, R., Faridullah, J. and Din, N. 2010. Wheat response to phosphorus under climatic conditions of Juglote, Pakistan. Sarhad J. Agri., 26: 229-33.

Din, J., Rashid, A. and Zahid, M.A. 2001. Optimizing productivity and profitability in rain fed legume crops through balanced nutrient management. Pakistan J. Soil Sci., 20 (4): 70-74.

Havlin, J.L., Tisdale, S.L., Beaton, J.D. and Nelson, W.L. 2007. Soil fertility and fertilizers - an introduction to nutrient management. Dorling Kindersley Pvt. Ltd., New Delhi, India. 175. 
Mc-Beath, T., MMc-Laughlin, M.J., Armstrong, B.R.D., Bell, M., Bolland, M.D.A. Conyers, M.K., Holloway, R.E. and Mason, S.D. 2007. Predicting the response of wheat (Triticum aestivum L.) to liquid and granular phosphorus fertilisers in Australian soils. Australian J. Soil Res., 45: 448- 458.

Mishra, V. N., Patil, S. K., Das, R. O. Shrivastava, L. K., Samadhiya, V. K. and Sengar, S. S. 2007. Site-specific nutrient management for maximum yield of rice in Vertisol and Inceptisols of Chhattisgarh. A paper presented in South Asian Conference on "Water in Agriculture: management options for increasing crop productivity per drop of water", during November 15-17, 2007 held at IGKV, Raipur (C.G.), India. pp. 136.

Ray, P.K., Jana, A.K., Maitra, D.N., Saha, M.N., Chaudhary, J., Saha, S. and Saha, A.R. 2000. Fertilizer prescriptions on soil test basis for Jute, Rice and Wheat in a Typic Ustochrept. J. of the Indian Society of Soil Sci. 48(1): 79- 84.

Sahu, N., Mishra, V.N., Srivastava, L.K. and Jatav, G. 2017. Crop Response based Assessment of Limiting Nutrients using
Site Specific Nutrient Management for Yield Maximization in Vertisols of Bemetara District of Chhattisgarh, India. Int. J. Curr. Microbiol. App. Sci., 6(6): 1784-1791.

Sakal, R. 2001. Efficient management of micronutrients for sustainable crop production. J. of the Indian Society of Soil Sci. 49(4): 593-608.

Sekhon, G.S. and Velayutham, M. 2002. Soil Fertility Evaluation. In: Fundamentals of Soil Science. Indian Society of Soil Science, New Delhi, 419-432.

Sharma, P.K., Yadav, G.L. and Kumar, S. 2000. Response of wheat to nitrogen and zinc fertilization. Indian J. Agro., 45(1): 124-127.

Singh, R. 2008. Effect of nitrogen management through organic and inorganic sources in sole and intercropped Bt cotton-wheat system. Ph.D. Thesis, Division of Agronomy, Indian Agri. Res. Institute, New Delhi, India. p. 99.

Syed, T.H., Ganai, M.R., Tahir Ali and Mir, A.H. 2006. Effect of nitrogen and sulphur fertilization on yield of and nutrient uptake by sunflower. J. Indian Soc. Soil Sci., 54(3): 375-376.

\section{How to cite this article:}

Balwant Kumar, G.K. Sharma, V.N. Mishra, A. Pradhan and Chandrakar, T. 2018. Assessment of Nutrient Deficiencies Based on Response of Rice (Oryza sativa L.) to Nutrient Omission in Inceptisols of Kondagaon District of Chhattisgarh in India. Int.J.Curr.Microbiol.App.Sci. 7(09): 350-359. doi: https://doi.org/10.20546/ijcmas.2018.709.043 